\title{
Indonesian Pesantren: The Need of New Civil Society
}

\author{
Ahmad Maghfurin', Muhammad Aqil Luthfan ${ }^{2}$ \\ Universitas Islam Negeri Walisongo Semarang ${ }^{1,2}$ \\ $\left\{\right.$ ahmad_maghfurin@walisongo.ac.id ${ }^{1}$, aqilluthfan@walisongo.ac.id²\}
}

\begin{abstract}
As educational institutions, Pesantren existed and took root in Indonesian society long before the Dutch Colonial Government introduced school education institutions. At the beginning of its appearance, this institution was oriented solely to religious interests. But in the modern era that prioritizes specialization in expertise, pesantren is faced with dilemma problems. On the one hand, it follows changes according to society's needs in the mainstream education system developed by the government. On the other hand, it desires to maintain his indigenous identity. This paper describes how pesantren, without leaving their original identity, modernize themselves to respond to society's demands, especially in terms of development of science and technology relating with the needs of work and ownership of formal diplomas.
\end{abstract}

Keywords: Pesantren; School; Madrasah; Modern; Traditional

\section{Introduction}

This study deals with the religious institute named in Indonesia as Pesantren, a type of educational institution in this country. Pesantren in the term of this study corresponds to the Zawiya or the Quranic School in Tunisia, Algeria, and Morocco, or what is known as Ribath in other Arab countries. It is a name for a classic institution for Islamic education where students and teachers live in one place. The institution named by the pesantren has these five elements: (1) the Teacher, Sheikh, Kyai, (2) Santri, educated students, (3) The mosque as a center of worship and education, (4) Ngaji, teaching Arabic Islamic heritage books, and (5) Pondok, housing where students live [1, p. 44]. All these elements combine in one place to become a particular community.

This type of institution appeared hundreds of years before the Dutch colonialists introduced the school system. There is no doubt that the Islamic institutes have succeeded in forming the righteous Indonesian Muslim generations since ancient times. This is appropriate for the national reconstruction program, which aims to develop the complete Indonesian people, an Indonesian people who believe in God, are created with decent morals, have the knowledge and a profession, are physically and spiritually correct, and have personality and responsibility in their society [2]. These goals stipulated in the Indonesian Law of Education recognized the importance of religious and moral conditions, and they are among the most significant concerns of Islamic institutes to achieve.

The pesantren aimed at the beginning of their inception to provide students with eschatological matters only. But in this modern era in which specializations are required in science and work, how do pesantrens develop in response to society's needs in these matters? 
What is its future? This study searched for the answer to these two questions based on what was found in the two Sharia institutes in northern Java, which are the APIK Pesantren in Kaliwungu-Kendal, and Futuhiyyah Pesantren in Mranggen-Demak. For this socioanthropological study, I participated in these two pesantrens' daily activities to obtain real perceptions regarding their advantages and disadvantages and made in-depth interviews with their superiors.

These two pesantrens do not represent all the pesantrens in Central Java in terms of quantity. Still, their selection is based on the characteristics according to the pesantren's response to the needs of the surrounding community. In this respect, each of these two pesantren is considered representative of the other pesantren that suit it. The APIK represents pesantren where education is based on providing students with Islamic sciences from their sources called Kitab Kuning (yellow books) - Indonesian naming the classic Islamic-Arabic books that students study in. Books bear this name because they are usually printed on yellow paper. The second pesantren, Futuhiyyah, does not differ at the beginning of its establishment from the pesantren mentioned above as the Center for Conclusion in Religion. But it has developed according to the passage of time by importing contemporary educational elements in terms of subjects and curricula without leaving the aspect of implanting Islamic morals based on education in the public pesantren in Indonesia.

\section{Result and Discussion}

\subsection{A General Pattern of the Growth of Pesantren}

Religious institutions in which the people of the country study have appeared since Islam's coming to Indonesia. It was the only type of educational institution of its time. At the beginning of its emergence, it was a simple institution to teach the Qur'an and how to perform rituals. This study process took place in mosques and Kyai's homes. Starting with the village people recognizing a Sheikh's knowledge and righteousness, the people around him came to learn about the Islamic religion until the world's fame reached the neighboring villages. After that, the educated were not just those who lived close to his home, but also the young men who came from far away, so that some of them could not return to their homes every day, so they lived in houses close to the kyai's house.

As for worship and people's social activities, they took place in the mosque. For this reason, the mosque was located in the center of the village, and the sheikh lived close to it, as he was the imam and teacher of his community. After each prayer, the sheikh gives a religious lecture to all residents, and at certain times he teaches the people of the village to read the Qur'an and translate it into the local language, how to worship and the principles of Islamic sciences such as jurisprudence, its fundamentals, interpretation, its sciences, grammar, rhetoric and others according to their stages [3].

At first, the sheikh was the only teacher, and advanced students sometimes helped him. And this situation continued until the school system came in the late nineteenth century AD. With the emergence of this new system, where pupils learn various academic subjects, the sheikh cannot teach all these subjects, so he invites specialized teachers from outside the pesantren. Many pesantren opened public schools in all their stages in response to the needs of the surrounding community.

The aforementioned mentioned that pesantren is the only type of educational institution in Java before attending public schools. It has a major role in training the country's youth to be 
leaders in their society. This process is based on a religious basis, which is learning the Islamic religion and teaching it to others, as every Muslim must seek knowledge with which he can perform their religious duties. At the same time, he is required to communicate their knowledge to others. Hence, it becomes evident that there is a strong link between learning and Islamic advocacy. Mosques, then, are places of worship and at the same time, centers of teaching Islam for all.

In principle, teaching children to the Islamic religion is the responsibility of the parents. Still, only a few can perform this function, so they send their children to kyais near their homes to learn from them. This religious phenomenon still exists in our present age. The country's people learn religious sciences in mosques and teachers' homes and in religious schools open in the evening and their learning in morning formal schools. Learning in mosques is considered introductory learning, in which students study the reading of the Qur'an and how to perform simple worship. Those who want to specialize in Islamic sciences go to pesantren under their kyais' supervision.

\subsection{Religious Institutes and the National Education System}

Historical study is necessary to know the position pesantren in the Indonesian national education system. This is because the Indonesian government's educational system is the school system that it inherited from Dutch Colonialism. This system was reflected from the very beginning on the pesantren that appeared and spread in society centuries before it. The education held by the colonial government aimed to provide the people with skills that would enable them to help colonialism preserve their interests in this country. In fact, opening these schools is not to educate the people, but to the needs of colonialism to workers who preserve their interests in this country $[4$, p. 148]. Therefore, the colonial education was reserved for the children of the elected [5, p. 48] (kaum priyayi) was based on worldly matters while teaching in religious institutes was based on the eschatological aspect. Hence, there are two types of education in Indonesia: public education in colonial schools and religious education in legal institutes. This situation continued until the country became independent.

After independence, the new government established public schools that provide students with the skills to work in various fields of life. So the young people preferred these schools more than their love for the Sharia institutes that only care about the other side. In response to this phenomenon, pesantren began to study sciences and skills useful for students' future life, just as public schools taught them. This change is because many scholars who have taught pesantren, are those who graduate from public schools and their studies in religious institutes. Besides, the Indonesian scholars who were educated in Saudi Arabia, Egypt, India, and the Arab professors from Syria and Tunisia who studied Arab children in Indonesia, became familiar with the Western education system [6, p. 102]. Contemporary Western educational elements entered Islamic institutes, and Islamic schools were established, similar to public schools, with increased Islamic sciences standards. On the other hand, the government introduced the Islamic Education Index in all public schools.

It should be noted that the pesantren do not develop in this one direction. Many of them remain in their original form, which is the center of figh in religion, with an increase in the teaching of specific public subjects. Despite this increase, graduates of this type of pesantren can only continue their studies in Islamic universities.

\subsection{The Balance between Science and Ethics}


The pesantren's response to the surrounding society's needs is evident in the inclusion of "secular" subjects in their curricula. Thus, it has public schools' capabilities to provide students with the principles of science and technology needed by the current society. It is one of the mainstays of modernization. This type of pesantren is distinguished from other schools by ethical values in addition to other sciences. And reaching the noble character is the real purpose of the education process in it [7, p. 22], [8]. And it is not the purpose of education in it is to fill the minds of the uplifted with information and teach them what they did not know of the academic subjects, instead the purpose is to refine their morals, establish virtue in them, accustom them to sublime manners and prepare them for their lives.

Attention to the ethical aspect does not diminish the attention given to the teaching of sciences and applied skills. Rather, it is the spirit of all the achievements that the teaching and education process attains. The pesantren's success in moral education is beyond doubt. It is known from daily life that it is successful for forming students who are committed to their religion and have decent morals. The pesantren that apply integrated education curricula, where all activities are united throughout the day and night, are able to give more than what public schools gave. The sheikh and teachers can monitor their students in their daily life.

Religious education is not the same as teaching other sciences. Religion is linked to values that are an issue of the conscience and can only be perceived by working with them and not merely knowing them [9, p. 42]. A person does not realize the values by thinking about them, but rather by practicing and recognizing them daily. The inculcation of these moral values requires adherence to them and that what students receive from teachers does not contradict the environment around them.

Whatever the matter of creating an integrated educational curriculum and drawing a solid plan for the growth of a person, organizing his talents and his psychological, emotional, emotional and behavioral life and exhausting his energies to the fullest, whatever it is of all of this, he does not dispense with the existence of an educational reality represented by an educator who achieves with his behavior and educational style all the foundations, methods and goals Which is intended to establish the educational curriculum on it. And the student in the school must set an example that he sees in each of his teachers or one of his teachers, in order to be truly convinced of what he learns and to see that what is required of him from the ideal behavior is realistic and feasible and that realistic happiness can only be achieved by applying it. A Muslim educator's life is a preacher's life to God, who needs to be an example to his students - and training students morally training based on studied books where teachers are role models for them leading to their awareness of values and their acquisition and adherence to them.

\subsection{Being a Religious Scholar is Not the Only Goal}

Pesantren is a social institution established to meet the needs of society in the educational field. In response to these needs, the disciplines present in the pesantren diversified. The educational goals in it are not limited to the implantation of scholars in religion, but on top of that is the hardening of scholars and intellectuals in the various fields of science that the contemporary society needs. They adhere to the teachings of their Islamic religion. The education process must be based on the following principles: Who knows whom, in what society, and at what time it takes place. In this type of pesantren, the divine and rational human sciences are taught simultaneously and in one place [10].

The Futuhiyah Pesantren in Mranggen Demak and similar pesantren are an example of this exemplary process. And the introduction of new "secular" sciences into their schools does not 
lead to abandoning the "old" religious values. The pupils are all studying in cricket schools and at the same time they participate in "passanthenic" activities such as group prayer, recitation of the verses and remembrance afterwards, reading the Qur'an and learning the principles of Islamic sciences.

And the expansion of disciplines in it does not mean that it neglects its establishment's original goal, which is to train scholars in religion. In keeping with this goal, those pesantren opened schools specialized in teaching Islamic sciences. All subjects studied in it refer to Arabic books and the use of the Arabic language as the language of instruction in the classroom and opening seminars for teaching classic Islamic books in their mosques and their teachers' homes. It is hoped from this program that working scholars and good advocates understand the matters of their society [11]. The diversity of disciplines within the pesantren indicates that the world in religion is not the only goal of the pesantren's students. The institute's graduates can be scholar, businessmen, doctors, or other professions [12].

Not all pesantren change this way. Pesantrens that remain in their original form, a place specializing in teaching Islamic sciences with all its arts, still exist today. An example is a pesantren APIK Kaliwungu Kendal. Although this pesantren implemented the school system, the study materials in it are all religious. Pupils who do not obtain an intermediate diploma study at the Crickleum Middle School located around it. From a personal interview I conducted with the director of this pesantren, I knew that choosing this form for his pesantren is not in the sense that it does not respond to the community's needs, but instead decided it for it, as public schools have been opened a lot. If all pesantrens are changing in this direction, then where will the scientists' implant in the future? So this pesantren undertook this responsibility.

\section{Conclusion}

I discovered from this study that the shape was not united in developing pesantren in Java, but rather in general Indonesia, but there are two significant currents represented in the two previously mentioned pesantrens. They either keep the pesantren in its original form to teach students pure religious sciences or accept contemporary educational elements [13]. And some pesantren have been proven in their old form not in the sense that they do not respond to the challenges of time, but for their sake, the presidents of this type of pesantrens chose them intending to graduate scholars specializing in Islamic sciences that society needs in various ages. On the other hand, public schools have been established in abundance, including in the pesantrens themselves. In fulfillment of the nine-year education compulsory program, the directors of this pesantren required pupils who did not obtain a middle school degree to pursue studies in the Kejar Paket or open public schools.

The pesantren has great powers with which it can be an ideal educational institution desirable to Indonesians. And the integrated school system throughout the day and night. The pesantren's full-day educational system and housing the students in private housing not separated from the sheikh's house enables it to give the pupils more than what the public schools gave. In this way, it is identical to what the busy fathers and mothers wanted, who do not have ample time to take care of raising their children. At the same time, the pesantren is able to train intellectuals and scholars in various fields of life who adhere to the teachings of their Islamic religion.

\section{References}


[1] Z. Dhofier, Tradisi Pesantren: Studi Tentang Pandangan Hidup Kyai, VI. Jakarta: LP3ES, 1994.

[2] U. Sisdiknas, “Undang Undang Sisdiknas No. 20.” Republik Indonesia, Jakarta, 2003.

[3] E. Susylowati, Sumarlam, W. Abdullah, and S. Marmanto, "Communication Used by Female Santri as Part of Their Social Interaction in Indoensian Modern Pesantren," Int. J. Innov. Creat. Chang., vol. 9, no. 7, 2019.

[4] Zuhairini, Sejarah Pendidikan Islam. Jakarta: Bumi Aksara, 1995.

[5] A. Suminto, Politik Islam Hindia Belanda. Jakarta: LP3ES, 1985.

[6] M. Yunus, Sejarah Pendidikan Islam di Indonesiia. Jakarta: Mutiara Sumber WIdya, 1995.

[7] M. A. Al-Abrasyi, Al-Tarbiyah al-Islamiyyah. Beirut: Dar al-Fikr, 1970.

[8] M. L. Fauzi, "Traditional Islam in Javanese Society: The Roles of Kyai and Pesantren in Preserving Islamic Tradition and Negotiating Modernity," J. Indones. Islam, vol. 6, no. 1, 2012.

[9] E. M. K. Kaswadi, Pendidikan Nilai Memasuki Tahun 2000. Jakarta: Grasindo, 1993.

[10] A. Fatchan, A. Amirudin, and H. Soekamto, "Education Model Bandongan for Farmers Society of Agricultural Skills Training in the Background of Socioculture Pesantren in East Java," Mediteranian J. Soc. Sci., vol. 6, no. 5, 2015.

[11] S. Maarif, "Reinventing Pesantren's Moderation Culture to Build a Democratic Scoiety in the Post-Reform Republic of Indonesia," Pertanika J. Soc. Sci. Humanit., vol. 27, no. 3, 2019.

[12] M. Sirry, "The Public Expression of Traditional Islam: The Pesantren and Civil Society in Post-Suharto Indonesia," Muslim World, vol. 100, no. 1, 2010.

[13] F. Pohl, "Islamic Education and Civil Society: Reflections on the Pesantren Tradition in Contemporary Indonesia," Comp. Educ. Rev., vol. 50, no. 3, 2006.

[14] A. M. Suryanegara, Menemukan Sejarah: Wacana Pergerakan Islam di Indonesia. Bandung: Mizan, 1995. 